\title{
An Investigation into the Ionic Chemical Composition and Mixing State of Biomass Burning Particles Recorded During TRACE-P P3B Flight\#10
}

\author{
C. H. SONG ${ }^{1,2, *}$, Y. MA ${ }^{1}$, D. ORSINI ${ }^{1}$, Y. P. KIM ${ }^{3}$ and R. J. WEBER ${ }^{1}$ \\ ${ }^{1}$ School of the Earth and Atmospheric Sciences, Georgia Institute of Technology, Atlanta, GA 30332, \\ U.S.A. \\ ${ }^{2}$ Department of Environmental Science and Engineering, Gwangju Institute of Science \\ and Technology (GIST), Gwangju 500-712, Korea, e-mail: chsong@gist.ac.kr \\ ${ }^{3}$ Department of Environmental Science and Engineering, Ewha Womans University, Seoul, Korea \\ * Corresponding author
}

(Received: 17 February 2004; accepted: 2 November 2004)

\begin{abstract}
In this study bulk airborne aerosol composition measured by the PILS-IC (integration time of 3 min $24 \mathrm{~s}$ ) during TRACE-P P3B Flight 10 are used to investigate the ionic chemical composition and mixing state of biomass burning particles. A biomass burning plume, roughly $3-$ 4 days old, moderately influenced by urban pollution aerosols recorded in the Philippine Sea is investigated. Focusing on the fine particle $\mathrm{NO}_{3}^{-}, \mathrm{SO}_{4}^{2-}, \mathrm{K}^{+}, \mathrm{NH}_{4}^{+}$, and water-soluble organics, the observed correlations and nearly 1-to- 1 molar ratios between $\mathrm{K}^{+}$and $\mathrm{NO}_{3}^{-}$and between $\mathrm{NH}_{4}^{+}$and $\left(\mathrm{SO}_{4}^{2-}+\right.$ inferred Organics) suggest the presence of fine-mode $\mathrm{KNO}_{3},\left(\mathrm{NH}_{4}\right)_{2} \mathrm{SO}_{4}$, and $\mathrm{NH}_{4}(\mathrm{Organics})$ aerosols. Under the assumption that these ion pairs existed, and because $\mathrm{KNO}_{3}$ is thermodynamically less favored than $\mathrm{K}_{2} \mathrm{SO}_{4}$ in a mixture of $\mathrm{NO}_{3}^{-}, \mathrm{SO}_{4}{ }^{2-}, \mathrm{K}^{+}, \mathrm{NH}_{4}^{+}$, and Organic anions, the measurements suggest that aerosols could be composed of biomass burning particles $\left(\mathrm{KNO}_{3}\right)$ mixed to a large degree externally with the $\left(\mathrm{NH}_{4}\right)_{2} \mathrm{SO}_{4}$ aerosols. A "closed-mode" thermodynamic aerosol simulation predicts that a degree of external mixing (by $\mathrm{SO}_{4}^{2-}$ mass) of 60 to $100 \%$ is necessary to achieve the observed ionic associations in terms of the existence of $\mathrm{KNO}_{3}$. However, the degree of external mixing is most likely larger than $90 \%$, based on both the presence of $\mathrm{KNO}_{3}$ and the amounts of $\mathrm{NH}_{4} \mathrm{NO}_{3}$. Calculations are also shown that the aerosol mixing state significantly impacts particle growth by water condensation/evaporation. In the case of P3B Flight \#10, the internal mixture is generally more hygroscopic than the external mixture. This method for estimating particle mixing state from bulk aerosol data is less definitive than single particle analysis, but because the data are quantitative, it may provide a complementary method to single particle chemical analysis.
\end{abstract}

Key words: aerosol mixing state, aerosol thermodynamic modeling, biomass burning particles, degree of external mixing, ionic association

\section{Introduction}

Biomass burning (hereafter, $\mathrm{BB}$ ) is an important source of atmospheric trace gases and particles (Andreae, 1983, 1988; Penner et al., 1992; Yamasoe et al., 2000; Andreae and Merlet, 2001; Sinha et al., 2003). These emissions could alter the 
atmospheric radiation budget and thereby influence regional and global climate (e.g., Penner et al., 1992; Kaufman and Fraser, 1997; Sinha et al., 2003). The chemical composition and mixing state of the BB particles could play a pivotal role in understanding these issues (Clarke et al., 2004). African Savanna and Brazilian Amazonian rainforest BB plumes have been chemically characterized (e.g., Yamasoe et al., 2000; Li et al., 2003; Sinha et al., 2003). The major particulate compounds and gaseous species emitted from Savanna fires and tropical forest burning include $\mathrm{CO}_{2}, \mathrm{CO}, \mathrm{NH}_{3}, \mathrm{NO}_{\mathrm{x}}, \mathrm{NMHCs}, \mathrm{K}^{+}, \mathrm{Cl}^{-}$, and $\mathrm{BC}$ (Andreae, 1983; Andreae and Merlet, 2001; Yamasoe et al., 2000; Sinha et al., 2003). However, there have been few studies investigating the aerosol mixing state of BB particles originating from these areas.

The NASA GTE TRACE-P (Global Tropospheric Experiment, Transport and Chemical Evolution over the Pacific) airborne research campaign conducted in spring, 2001, over East Asia, provided an opportunity to investigate BB emissions and its influence on the composition of air masses advected from Asia. Ma et al. (2003) extensively analyzed the particulate data measured by the NASA P3B aircraft during the TRACE-P campaign to investigate the influences of BB emissions on the fine particle ionic composition. They concluded that approximately $20 \%$ of the plumes encountered by the NASA P3B aircraft during the intensive portion of the experiment were influenced by $\mathrm{BB}$ emissions, based on concentrations of fine particle $\mathrm{K}^{+}$, a marker for BB emissions. Although Ma et al. investigated the sources and chemical characteristics of the TRACE-P BB plumes, no attempt was made to characterize ionic associations and mixing state of the $\mathrm{BB}$ particles.

In this study, we focus on a representative BB plume (Flight \#10) to examine the ionic associations and mixing state of $\mathrm{BB}$ particles by analyzing the ion correlations and charge balances among measured ionic constituents. Flight \#10 is selected because it contains relatively pure BB emissions, simplifying our analysis (Ma et al., 2003). In contrast, many of the other plumes (e.g., Flights 14 and 19) were composed of complicated mixtures of particles from a variety of sources, including bio-fuel and fossil fuel emissions, and natural aerosols such as dust and sea-salt particles.

Aerosol mixing state is important because it affects the particles physical properties and chemical evolution. Many researchers have investigated the degree to which atmospheric aerosols are mixed (e.g., Covert and Heintzenberg, 1984; Zhang et al., 1993; Parungo et al., 1994; Cooke and Wilson, 1996; Eldering and Cass, 1996; Haywood et al., 1997; Kleeman et al., 1997), however, in many atmospheric situations it is not well characterized. It is generally assumed that for relatively young air masses (e.g., urban aerosols), particles mostly exist as external mixtures (e.g., Covert and Heintzenberg, 1984; Wexler et al., 1994; Eldering and Cass, 1996; Kleeman et al., 1997), whereas particles in aged air mass (e.g., aerosols in the free troposphere or remote regions) are likely internally mixed (e.g., Cooke and Wilson, 1996; Parungo et al., 1996). In the BB plumes investigated here, the air masses are relatively old and were encountered in the remote mid-troposphere. 
It has been recognized that bulk aerosol particle composition data provide limited insight into individual particle composition and mixing state, and that only "single particulate chemical analysis" can directly provide such information (e.g., Guazzotti et al., 2001; Li et al., 2003; Posfai et al., 2003; Zhang et al., 2003). However, size-resolved chemical data have also been used to infer particle mixing state based on similarities in size distributions of various chemical components (e.g., Allan et al., 2003). In this study, we investigate spatial (and thus temporal) correlations and charge balances between compounds to provide insight into possible ion associations, and then compare these associations with a thermodynamic model. This new method is based on a relatively short bulk chemical composition measurement rate ( 3 min $24 \mathrm{~s}$ ). When such a bulk measurement is made by an aircraft through a widespread plume influenced by a single spatially large source (here, biomass burning), an ensemble of the measured bulk ionic concentrations are obtained. The method is based on the assumption that from the ensemble of the bulk ionic concentration measurements, the variability in particulate concentration within the plume, and uniformity over a single measurement integration time (3 $\min 24 \mathrm{~s}$ ), can provide insight into associations between ion pairs.

\section{Experimental Procedures}

The PILS-IC (Particle Into Liquid Sampler coupled to a dual channel ionchromatograph) measured the fine-particle inorganic chemical composition on the P3B. In this instrument, sample air is first drawn through annular diffusion denuders to remove interfering gases and then rapidly mixed with saturated water vapor to produce a supersaturated environment. Ambient particles in the sample air are activated and grow to sizes that permits captured by inertial impaction onto a wetted surface. With the addition of a small transport flow of purified water $(\sim 0.1 \mathrm{~mL} / \mathrm{min})$, the resulting liquid flow containing the water-soluble aerosol components is then analyzed continuously via anion and cation ion chromatography. Based on baseline noise from the measurements of ambient air, detection limits are calculated to be in the range of $40-60 \mathrm{ng} / \mathrm{m}^{3}$ for cations and approximately $10 \mathrm{ng} / \mathrm{m}^{3}$ for anions.

During this experiment, the instrument was configured for a 4-min sampling cycle, each with a 3-min 24-s sample integration period (Weber et al., 2001; Orsini et al., 2003). The PILS-IC sampled with a low turbulence inlet (LTI) to minimize large particle losses (Huebert et al., 2004). Note, that in these experiments the PILS-IC measurements only provided fine-mode aerosol composition, where finemode is defined here as particles with aerodynamic diameter less than nominally $1.3 \mu \mathrm{m}$, the size at $50 \%$ collection efficiency. Based on laboratory experiments, this collection efficiency is inherent to the early PILS design and is due to losses in the PILS turbulent mixing of steam with ambient air. More recent PILS are capable of sampling up to nominally $10-\mu \mathrm{m}$-diameter particles with $100 \%$ efficiency (Orsini et al., 2003). 


\section{Analysis and Discussions}

TRACE-P objectives were to identify the major pathways for Asian outflow over the Northwestern Pacific oceans, to chemically characterize the outflow, and estimate contributions from different sources, (e.g., BB and fossil-fuel combustion), to the East Asian outflow (Jacob et al., 2003). Two NASA aircraft (Wallops P3B and Dryden DC8) were deployed during this experiment to achieve these objectives. In this paper, we will focus on a representative BB plume (P3B Flight \#10) to investigate the ionic associations and mixing state of the $\mathrm{BB}$ aerosols.

\subsection{AIR TRAJECTORIES AND PLUME COMPOSITION}

The P3B Flight \#10 plumes observed on March 9, 2001, between 2:58-3:46 (1st leg) and 5:05-5:38 (2nd leg) UTC, were apparently influenced by biomass burning activities in South Asia, based on back trajectories and evidence of burning from fire-maps generated from satellite observations. Black Carbon emissions in Figure 1 are estimated based on satellite fire map observations, (see Ma et al., (2003) for more details). The plumes were composed of high concentrations of fine-mode particulate $\mathrm{K}^{+}$, light absorbing particles (e.g., black carbon), and gases often associated with biomass burning, such as $\mathrm{CH}_{3} \mathrm{Cl}$ (Andreae and Merlet, 2001; Sinha et al., 2003). Based on the measured aerosol size distributions (personal communication, Prof. Anthony Clarke, U. of Hawaii), and an assumed particle density of $1.5 \mathrm{~g} / \mathrm{cm}^{3}$ (Hinds, 1982), the average aerosol mass in the biomass plume is estimated to range between 35 and $86 \mu \mathrm{g} / \mathrm{m}^{3}$, significantly higher than background mid-tropospheric aerosols (Jaenicke, 1993). The average particle surface areas are between 160 and

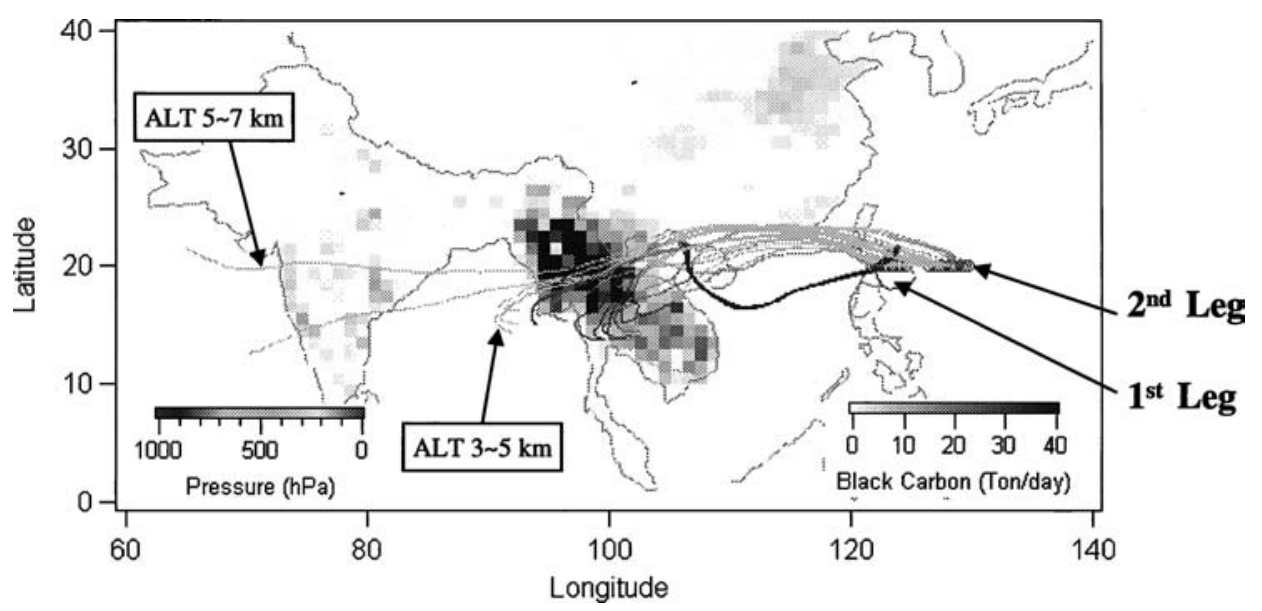

Figure 1. Five-day back trajectory analysis for air masses encountered during TRACE-P P3B Flight \#10. The measurements are divided into two legs each of which contains high levels of fine-mode $\mathrm{K}^{+}$. Also, shown are spatial distributions of biomass black carbon emission. 
$600 \mu \mathrm{m}^{2} / \mathrm{cm}^{3}$ in the biomass plume. Ma et al. (2003) discussed the characteristics of these plumes in more detail.

These biomass burning plumes were measured over the ocean north of the Philippines in the Luzon Straight above the marine boundary layer defined by a temperature inversion at $\sim 2.3 \mathrm{~km}$. The BB plume was observed at altitudes ranging from the inversion to $\sim 3.5 \mathrm{~km}$ (vertical profiles of species concentrations and temperature variation can be found in Figure 3 of Ma et al., 2003). Figure 1 shows the 5-day back trajectories for these air masses (they can also be found at http://bertha.met.fsu.edu/ tracep/). For these air masses most of the back trajectories extend back to the mid-troposphere at $\sim 6 \mathrm{~km}$ over the Indian Ocean and remote tropical rainforest regions. Thus, these air parcels are expected to contain mid-tropospheric background aerosols. In transit to the interception points, the air parcels experience significant injections from the tropical forest burning over Thailand, Myanmar, southern parts of China, and northern parts of Vietnam, 3-4 days prior to the plume measurements. These fires are clearly identified from satellite fire map images (AVHRR from the World Fire Web (WFW, http://www.gvm.jrc.it/tem/wfw/wfw.htm)). From this point in time, one can assume that the air masses are a mixture of background mid-tropospheric air and tropical forest burning plumes, and that the particles in the plume begin to evolve due to chemical and physical processes.

The mid-tropospheric background "fine-mode" aerosol particles are likely composed of $\left(\mathrm{NH}_{4}\right)_{2} \mathrm{SO}_{4}$, which are often found throughout the free troposphere (Murphy et al., 1998). Also, at altitudes above the BB plumes where fine-mode $\mathrm{K}^{+}$ concentrations are low (i.e., outside the BB plumes), the PILS data also suggests that the main fine particle ionic constituents are $\mathrm{NH}_{4}^{+}$and $\mathrm{SO}_{4}^{2-}$.

The major particulate compounds and their precursors emitted from tropical forest burning and Savanna fires include $\mathrm{CO}_{2}, \mathrm{CO}, \mathrm{NH}_{3}, \mathrm{NO}_{\mathrm{x}}, \mathrm{NMHCs}, \mathrm{K}^{+}, \mathrm{Cl}^{-}$, and BC (Andreae, 1983; Andreae and Merlet, 2001; Yamasoe et al., 2000; Sinha et al., 2003). According to Andreae and Merlet (2001), the amounts of $\mathrm{NO}_{\mathrm{x}}$ (as NO) emitted from the tropical forest burning are, on average, $\sim 3$ times larger than the amount of $\mathrm{SO}_{2}$, based on estimated emission factors. Sinha et al. (2003) report that in savanna fires $\mathrm{NO}$ emissions are larger than $\mathrm{SO}_{2}$ emissions by a factor of $\sim 10$. Therefore, unless large amounts of $\mathrm{SO}_{2}$ are supplied by entrainment of background air into the $\mathrm{BB}$ plume, we could expect $\mathrm{HNO}_{3}$ mixing ratios inside the $\mathrm{BB}$ plume to be much higher than $\mathrm{H}_{2} \mathrm{SO}_{4}$ mixing ratios. Thus, the $\mathrm{BB}$ particles are likely exposed to high levels of $\mathrm{HNO}_{3}$ and have chemically evolved by interaction with $\mathrm{HNO}_{3}$ rather than by interactions with $\mathrm{H}_{2} \mathrm{SO}_{4}$. As shown in Figure 1, in our case the background air masses above the plume come from ocean and continental remote areas at $\sim 6 \mathrm{~km}$ above sea level, and traveled through the free troposphere along the way to the point of measurement. In summary, based on these arguments, it seems reasonable to expect that the $\mathrm{BB}$ particles were exposed to higher levels of $\mathrm{HNO}_{3}$ than $\mathrm{H}_{2} \mathrm{SO}_{4}$ between the time they were injected into the atmosphere and measured. 


\subsection{CORRELATION ANALYSIS}

Possible associations between various cation-anion pairs in the BB plume are investigated based on correlations and molar ratios between ion pairs. It is noted that in the airborne measurement temporal correlations actually imply spatial correlations.

Figure 2(a) and (b) present correlations between cations $\mathrm{K}^{+}$and $\mathrm{NH}_{4}^{+}$, and anions $\mathrm{NO}_{3}^{-}$and $\mathrm{SO}_{4}^{2-}$ for measurements within the biomass burning plumes of Flight 10 . As shown, $\mathrm{K}^{+}$is closely correlated with $\mathrm{NO}_{3}^{-}(R=0.92)$ and has a near 1-to-1 molar ratio (Slope $=1.08$ ), and intercept that is closed to 0. However, $\mathrm{K}^{+}$and $\mathrm{SO}_{4}^{2-}$ are not correlated at all $(R=0.03 ; S=0.03)$. These results are consistent with $\mathrm{K}^{+}$being almost exclusively associated with $\mathrm{NO}_{3}^{-}$. On the other hand, $\mathrm{NH}_{4}^{+}$is well correlated with $\mathrm{SO}_{4}^{2-}(R=0.66)$ and suggests that $\mathrm{NH}_{4}^{+}$could be neutralized by $\mathrm{SO}_{4}^{2-}$ (here, the level of $\mathrm{NO}_{3}^{-}$is low compared to $\mathrm{SO}_{4}^{2-}$ ).

These associations can also be examined by comparing the measured cations and anions along the measurement legs of Flight 10 . The combined passes through the plumes produced a total of 20 data points of PILS-IC measurements available for analysis. As shown in Figure $3(\mathrm{a}), \mathrm{K}^{+}$is well correlated with $\mathrm{NO}_{3}^{-}$along the
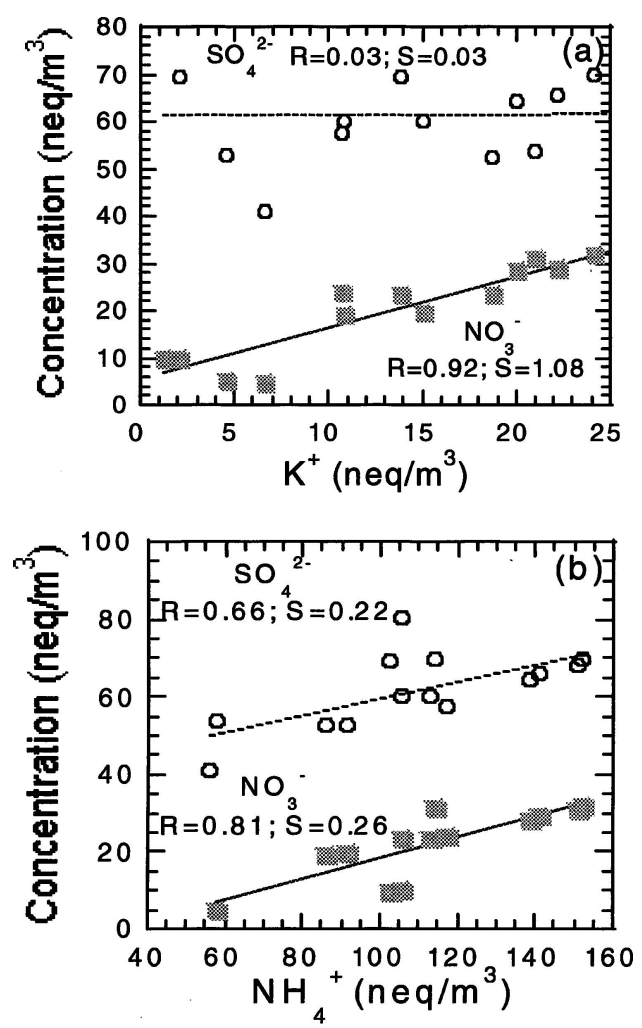

Figure 2. Correlations analyses: (a) between measured $\mathrm{K}^{+}$and measured $\mathrm{NO}_{3}^{-} / \mathrm{SO}_{4}^{2-}$; and (b) between measured $\mathrm{NH}_{4}^{+}$and $\mathrm{NO}_{3}^{-} / \mathrm{SO}_{4}^{2-}$. In the each panel, $\mathrm{R}$ and $\mathrm{S}$ represent the correlation coefficient and the slope of the linear plots, respectively. 

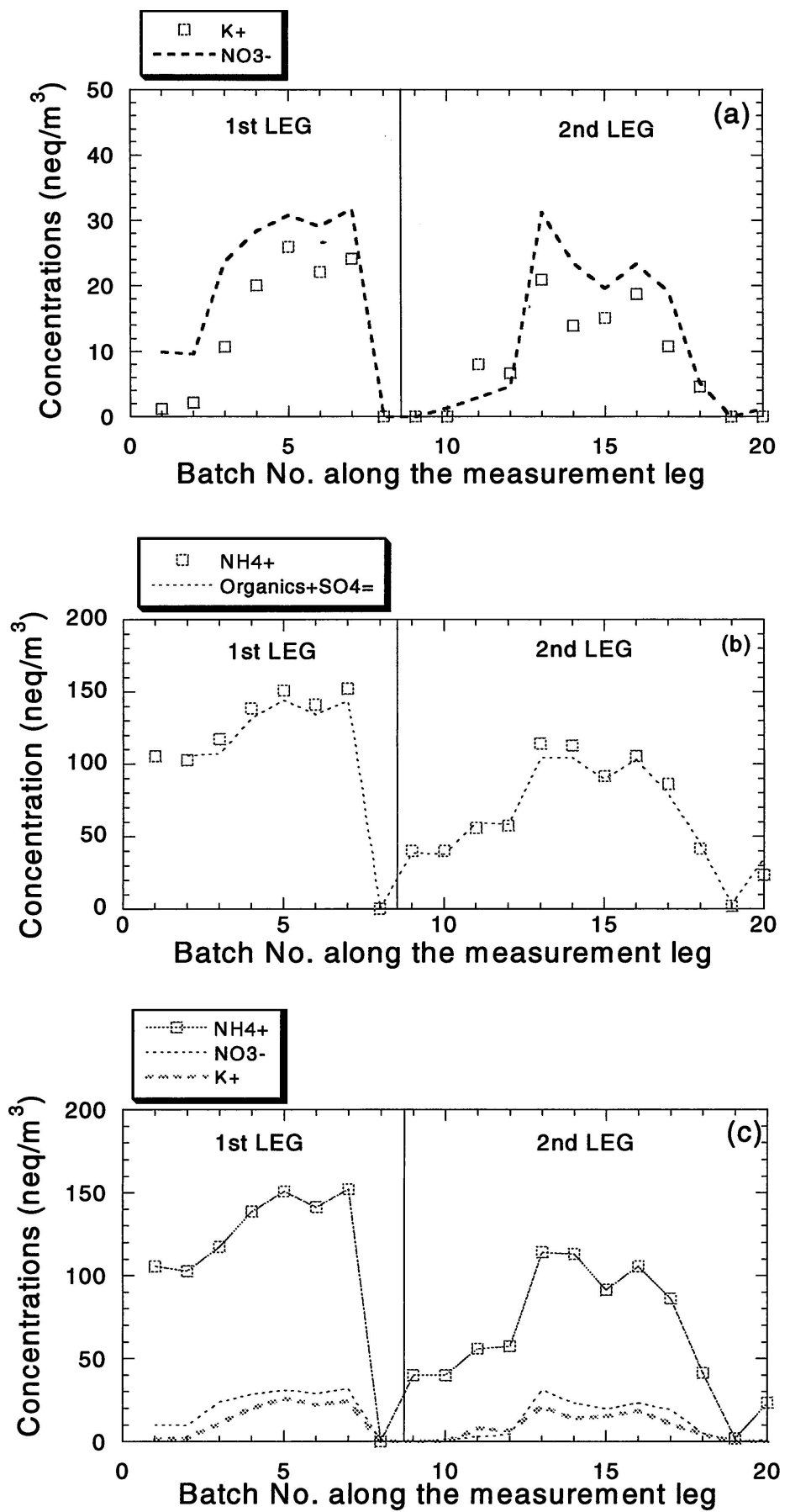

Figure 3. Correlations analyses (a) between measured $\mathrm{K}^{+}$and $\mathrm{NO}_{3}^{-}$; (b) between measured $\mathrm{NH}_{4}^{+}$and $\mathrm{SO}_{4}^{2-}+$ Organics along the measurement leg; and (c) between measured $\mathrm{NH}_{4}^{+}$and $\mathrm{NO}_{3}^{-}$. 
measurement legs, and molar concentrations (equivalences) of $\mathrm{K}^{+}$and $\mathrm{NO}_{3}^{-}$are also in near balance. These two observations suggest that $\mathrm{K}^{+}$and $\mathrm{NO}_{3}^{-}$, or their precursors were co-emitted in the BB plume (by correlation) and likely bound with each other (by near equal equivalences). Of course, there may be a very low possibility that the nearly perfect correlation between $\mathrm{K}^{+}$and $\mathrm{NO}_{3}^{-}$is just fortuitous and result from variability in the spatial source strength of $\mathrm{K}^{+}$and $\mathrm{NO}_{3}^{-}$(or their precursors) and random mixing, although this seems unlikely.

As discussed in Section 3.1, the BB particles are more likely exposed to high levels of $\mathrm{HNO}_{3}$ than $\mathrm{H}_{2} \mathrm{SO}_{4}$. This means that the fresh $\mathrm{BB}$ particles, which are thought to be initially composed of $\mathrm{KCl}$ (Yamasoe et al., 2000; Li et al., 2003), have most likely chemically evolved by $\mathrm{HNO}_{3}+\mathrm{KCl}$ reactions, due to the abundance of $\mathrm{HNO}_{3}$.

Figure 2(b) showed that $\mathrm{NH}_{4}^{+}$is strongly correlated with $\mathrm{SO}_{4}^{2-}$. Although this strong correlation is consistent with $2 \mathrm{NH}_{4}^{+}-\mathrm{SO}_{4}^{2-}$ association, throughout the measurement legs of the biomass burning plumes cations are always more abundant. This could imply that not all the major anionic components were measured. Many investigators have reported that $\mathrm{BB}$ aerosols contain a significant fraction of watersoluble formate $\left(\mathrm{HCOO}^{-}\right)$, acetate $\left(\mathrm{CH}_{3} \mathrm{COO}^{-}\right)$, oxalate $\left(\mathrm{C}_{2} \mathrm{O}_{4}{ }^{2-}\right)$, and other organic anions such as malonate, succinate, and glutarate (Andreae et al., 1988; Talbot et al., 1988; Tabazadeh et al., 1998; Yamasoe et al., 2000; Gao et al., 2003). Water-soluble organics were not measured with the PILS-IC during these airborne experiments since they require longer integration times $(\sim 15 \mathrm{~min}$ for isocratic chromatographic separation) and thus limit the sampling rate. Even so, the watersoluble organic concentrations can be estimated from the measured cation and anion concentrations by the following mole balance:

$$
[\text { Organics }]_{\text {estimated }}=\sum_{i}^{n}[\text { Cation }]_{\text {measured }, i}-\sum_{j}^{m}[\text { Anion }]_{\text {measured }, j}
$$

where, organic equivalence ([Organics $]_{\text {estimated }}$ ) is assumed to be the sum of $\left[\mathrm{HCOO}^{-}\right]+\left[\mathrm{CH}_{3} \mathrm{COO}^{-}\right]+\left[\mathrm{C}_{2} \mathrm{O}_{4}{ }^{2-}\right]+[$ Other organic anions $]$. In this estimation, we have assumed that the particles are charge-neutral and that the organic acids are the only major ions not measured. The equivalences of hydrogen and hydroxyl ions (i.e, $\left[\mathrm{H}^{+}\right]$and $\left[\mathrm{OH}^{-}\right]$) are not considered in this analysis because most particles are expected to be dry at the measured relative humidity (this will be further discussed in Section 3.3). Also, other unmeasured crustal anionic species (e.g., $\mathrm{CO}_{3}{ }^{2-}$ ) are ignored since the measured $\mathrm{Ca}^{2+}$ and $\mathrm{Mg}^{2+}$ concentrations in the plume were very low (the BB usually emit some crustal elements due to re-suspension caused by strong turbulence). This can be seen in Table I where the concentrations of the ions measured in the BB plume are summarized. (Note in Table I, only every third PILS-IC measurement is tabulated and only these points will be analyzed later.) Figure 3(b) shows the correlations between $\mathrm{NH}_{4}^{+}$and $\left(\mathrm{SO}_{4}^{2-}+\right.$ Organics). Good correlation (co-emitted) and molar balances (ion association) between $\mathrm{NH}_{4}^{+}$and 


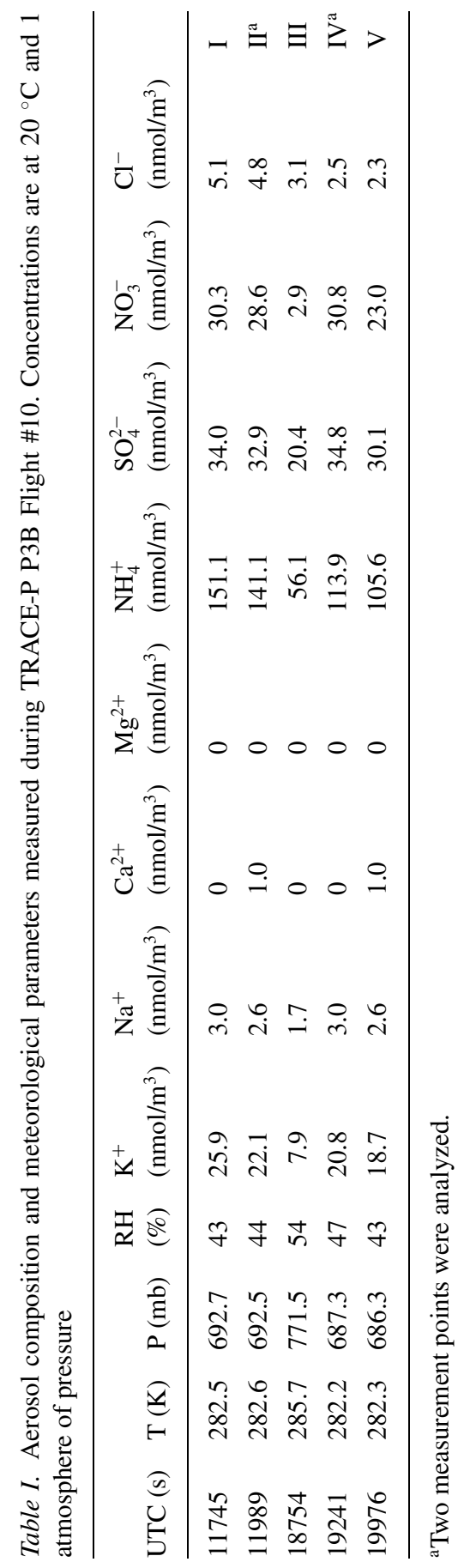


$\mathrm{SO}_{4}^{2-}+$ Organic anions can be seen in Figure 3(b) throughout both measurement legs. The percentage of $\mathrm{SO}_{4}^{2-}$ in $\mathrm{SO}_{4}{ }^{2-}+$ Organic anions is estimated to be in the range of $50-70 \%$ for the $1 \mathrm{st}$ leg, and $25-90 \%$ for the 2 nd leg.

Nitrate could also be associated with $\mathrm{NH}_{4}^{+}$. Although Figure 2(b) shows that there is a good correlation $(R=0.81)$ between these ions, Figure 3(c) shows that the equivalence level of $\mathrm{NO}_{3}^{-}$is too low to completely neutralize the $\mathrm{NH}_{4}^{+}$.

$\mathrm{NH}_{4} \mathrm{NO}_{3}$ is a highly volatile salt that has been reported in urban settings (not in remote areas), in which there exist high levels of gaseous $\mathrm{NH}_{3}$ and $\mathrm{HNO}_{3}$, like Los Angeles (Bassett and Seinfeld, 1983; Seinfeld and Pandis, 1998; Neuman et al., 2003 and references therein). However, as the plume evolves and the gaseous species are diluted, $\mathrm{NH}_{4} \mathrm{NO}_{3}$ tends to be dissipated into the gas phase due to its high volatility. Unfortunately, gas-phase $\mathrm{NH}_{3}$ was not measured during the TRACE-P P3B Flight \#10. However, $\mathrm{HNO}_{3}$ was measured during LEG2. The observed levels of $\mathrm{HNO}_{3}$ range between 506 pptv and 1462 pptv (avg. = 917.8 pptv). With these values, we estimate the level of gaseous $\mathrm{NH}_{3}$ at which $\mathrm{NH}_{4} \mathrm{NO}_{3}$ salt formation could be triggered, at the measured temperature $(282.6 \mathrm{~K})$ and pressure $(0.71 \mathrm{~atm})$. Using the formula given by Kim and Seinfeld (1993a), the required $\mathrm{NH}_{3}$ levels range from 1310 to 3780 pptv (i.e., using $\mathrm{P}_{\mathrm{NH}_{3}}=K_{282.6} / \mathrm{P}_{\mathrm{HNO}_{3}}$ ) (for $\left[\mathrm{HNO}_{3}\right]_{\text {avg }} .=917.8$ pptv, the required $\left[\mathrm{NH}_{3}\right]=2085.5$ pptv). Because salt formation can occur when gaseous $\mathrm{NH}_{3}$ levels are even higher than these estimated levels, the estimated $\mathrm{NH}_{3}$ level can be regarded as a threshold concentration for $\mathrm{NH}_{4} \mathrm{NO}_{3}$ formation. Such high concentrations of gas-phase $\mathrm{NH}_{3}$ may be highly unlikely over the measurement tracks when one considers its very highly hydrophilic nature and large amounts of $\mathrm{NH}_{4}^{+}$already consumed by combining with sulfates. Indeed, $\mathrm{NH}_{3}$ levels in marine sites reported by Adams et al. (1999) range from a few pptv to $\sim 1000$ pptv (maximum value). Also, according to their 3D simulation study that considered $\mathrm{BB} \mathrm{NH}_{3}$ emissions, the predicted $\mathrm{NH}_{3}$ levels near the Luzon Straight of Philippine Islands were about 30-300 pptv. Thus, the existence of large $\mathrm{NH}_{4} \mathrm{NO}_{3}$ salt concentrations in the measurement track of TRACE-P P3B Flight \#10 is unlikely. Moreover, given the $\mathrm{K}^{+}-\mathrm{NO}_{3}^{-}$equivalence ratios shown in Figure 3(a) and (b) is nearly $1: 1$ and $\mathrm{NH}_{4}^{+}-\mathrm{NO}_{3}^{-}$is not, the presence of $\mathrm{KNO}_{3}$ salts seems more plausible. Although it is highly unlikely that $\mathrm{NH}_{4} \mathrm{NO}_{3}$ is formed inside the $\mathrm{BB}$ plumes, it is possible that some small amount of $\mathrm{NH}_{4} \mathrm{NO}_{3}$ could have been entrained or injected from the polluted MBL below the BB plumes (refer to Figure 3 in Ma et al., 2003). This would explain the slightly higher $\mathrm{NO}_{3}^{-}$concentrations compared to $\mathrm{K}^{+}$seen in Figure 3.

The inferred major association between $\mathrm{NH}_{4}^{+}$and $\mathrm{SO}_{4}^{2-}$ could result from two sources: (1) entrainment of pre-existing $\left(\mathrm{NH}_{4}\right)_{2} \mathrm{SO}_{4}$ particles into the $\mathrm{BB}$ plume from mid-tropospheric background air and entrainment of MBL air below the measurement track (Ma et al., 2003); and (2) newly created and grown accumulation-mode particles inside the BB plume. The former was already discussed in Section 3.1 and by Ma et al. (2003), respectively. The latter is also possible because BB emits $\mathrm{NH}_{3}$ (Andreae and Merlet, 2001; Sinha et al., 2003). This 
gaseous ammonia could participate in nucleation with $\mathrm{H}_{2} \mathrm{O}$ and $\mathrm{H}_{2} \mathrm{SO}_{4}$ via a ternary nucleation mechanism (Weber et al., 1998; Korhnon et al., 1999; Napari et al., 2003, references therein). As shown in Figure 1, the BB air masses have traveled through the mid-troposphere $(3-6 \mathrm{~km})$ and thus the air mass temperatures were likely low throughout this transit period. Both low temperature and high gas-phase plume $\mathrm{NH}_{3}$ concentrations create favorable conditions for new particle formation. These newly created particles, composed of $2 \mathrm{NH}_{4}^{+}-\mathrm{SO}_{4}^{2-}-\mathrm{H}_{2} \mathrm{O}$, could then grow into the accumulation-mode particles by condensations of water and other species (e.g., $\mathrm{NH}_{3}$ and $\left.\mathrm{H}_{2} \mathrm{SO}_{4}\right)$. Furthermore, inside the smoke plumes from tropical forest burning, sulfate is very rapidly formed $(\sim 1 \mathrm{~min})$ at the surface of BC (black carbon) via heterogeneous pathways (Novakov et al., 1974; Meszaros and Meszaros; 1989; Yamasoe et al., 2000). The sulfate produced in this manner could be rapidly neutralized by $\mathrm{NH}_{4}^{+}$. It is noted that $\mathrm{BC}$ is often found with $\left(\mathrm{NH}_{4}\right)_{2} \mathrm{SO}_{4}$ in the remote atmosphere (Clarke et al., 2004). Indeed it is due to both nucleation/condensation and heterogeneous reactions on $\mathrm{BC}$, that $\left(\mathrm{NH}_{4}\right)_{2} \mathrm{SO}_{4}$ particles are found to be the most abundant species in regional hazes and the free troposphere directly affected by Savanna fires over southern Africa (Li et al., 2003).

In the following section, these findings are compared to the thermodynamic predictions of ion-pair associations when the particles are internally mixed. For example, is the association between $\mathrm{K}^{+}$and $\mathrm{NO}_{3}^{-}$thermodynamically possible if $\mathrm{SO}_{4}^{2-}$ co-exists in the same particles? If such an association is not thermodynamically preferred, then some degree of external mixing must exist between $\mathrm{K}^{+}$and $\mathrm{SO}_{4}^{2-}$.

\subsection{AEROSOL THERMODYNAMIC ANALYSIS}

In order to investigate the thermodynamically favorable associations among the measured cations and anions, a "close-mode (or intraparticulate mode)" thermodynamic aerosol model simulation is performed (Jacobson et al., 1996; Meng et al., 1998), using the SCAPE II model (Simulating Composition of Aerosol Particles at Equilibrium II). The SCAPE II model is described in detail elsewhere (Kim and Seinfeld, 1993a,b; Meng et al., 1995), and only discussed briefly here. The aerosol thermodynamic model can predict the particle composition at the equilibrium state where the Gibbs free energy of the particulate phase is at a minimum. This implies that the aerosols are in the most stable state for the given measured particle concentrations, $\mathrm{RH}$, and temperature. It is assumed that intra-particle equilibrium is achieved rapidly, and thus that one can theoretically examine particle composition with a thermodynamic model (Jacobson et al., 1996; Meng et al., 1998). The SCAPE II is one of the many aerosol thermodynamic models available. Here, a "close-mode" SCAPE simulation is conducted, because the PILS-IC only measured the particulate composition.

Table I summarizes the aerosol composition and meteorological parameters measured within the BB plumes of P3B Flight 10, between 2:58-3:46 and 
5:05-5:38 (UTC). To limit the number of plots, only every third data point among the original measurements in the plume is chosen for further analysis. The other data have similar characteristics.

\subsubsection{Internal Mixture}

The internal mixture case is explored first since it is the most straightforward to implement. Note, it is generally assumed that aerosol particles in aged air masses are internally mixed. In this case, all the measured species are assumed to exist in "one particle". Chemical composition, RH, and temperature, shown in Table I, are input into the "close-mode" SCAPE II simulation. Figure 4 presents the simulation results for selected PILS measurements in the biomass burning plume. Although mass fractions of the various salts differ between the various measurements, the type of predicted salts are similar in all cases. Major salts are $\left(\mathrm{NH}_{4}\right)_{2} \mathrm{SO}_{4}, \mathrm{NH}_{4} \mathrm{NO}_{3}$, and $\mathrm{K}_{2} \mathrm{SO}_{4}$. Here, note also, that our model only predicts salts. The measured RHs in Table I are lower than DRHs (Deliquescence Relative Humidities) of all the predicted salts. This is the basis on which we ignored the $\mathrm{H}^{+}$and $\mathrm{OH}^{-}$concentrations in the estimation of water-soluble organic concentrations Equation (1). In Figure 4, $\mathrm{R}^{-\mathrm{NH}_{3}}$ represents the "remaining $\mathrm{NH}_{4}^{+}$". As discussed previously, all the PILS-IC data of P3B Flight \#10, 2:58-3:46 and 5:05-5:38 UTC (biomass plume) are cation-abundant. The cation-abundance could be caused by not measuring the organic anions such as formate, acetate, oxalate ions, and others. Thus, the "remaining $\mathrm{NH}_{4}^{+}$" is postulated to be associated with those unmeasured organic anions (Tabazadeh et al., 1998; Gao et al., 2003). The salient feature of the modeling results is that no $\mathrm{KNO}_{3}$ is predicted, in contradiction to our correlation analysis (it also predicts large fractions of $\mathrm{NH}_{4} \mathrm{NO}_{3}$, which, as discussed above, appears unlikely). This discrepancy suggests that the assumed aerosol mixing state in the simulation is incorrect and that $\mathrm{K}^{+}$and $\mathrm{SO}_{4}^{2-}$ are not completely internally mixed.

\subsubsection{External Mixture}

In order to investigate the effect of an external mixture on ion associations, varying amounts of $\left(\mathrm{NH}_{4}\right)_{2} \mathrm{SO}_{4}$ are removed from the bulk internal mixture. The amount of $\left(\mathrm{NH}_{4}\right)_{2} \mathrm{SO}_{4}$ removed can be viewed as the amount that exists externally to the $\mathrm{BB}$ aerosols which contains $\mathrm{K}^{+}$. The reasons for selecting $\left(\mathrm{NH}_{4}\right)_{2} \mathrm{SO}_{4}$ for removal are two fold: (1) this salt is believed to be the major constituents of background aerosols in the mid-troposphere and in the polluted MBL air below the BB plume (we have assumed that the air parcels encountered by Flight 10 are a mixture of background air masses, air masses entrained from the polluted MBL, and BB plumes); and (2) unlike $\mathrm{K}^{+}$which is emitted directly from $\mathrm{BB},\left(\mathrm{NH}_{4}\right)_{2} \mathrm{SO}_{4}$ particles in the $\mathrm{BB}$ plumes could be secondarily formed by nucleation/condensation and heterogeneous reactions on $\mathrm{BC}$, as discussed in the Section 3.2. Because of these different formation mechanisms, it is reasonable that these two different types of 

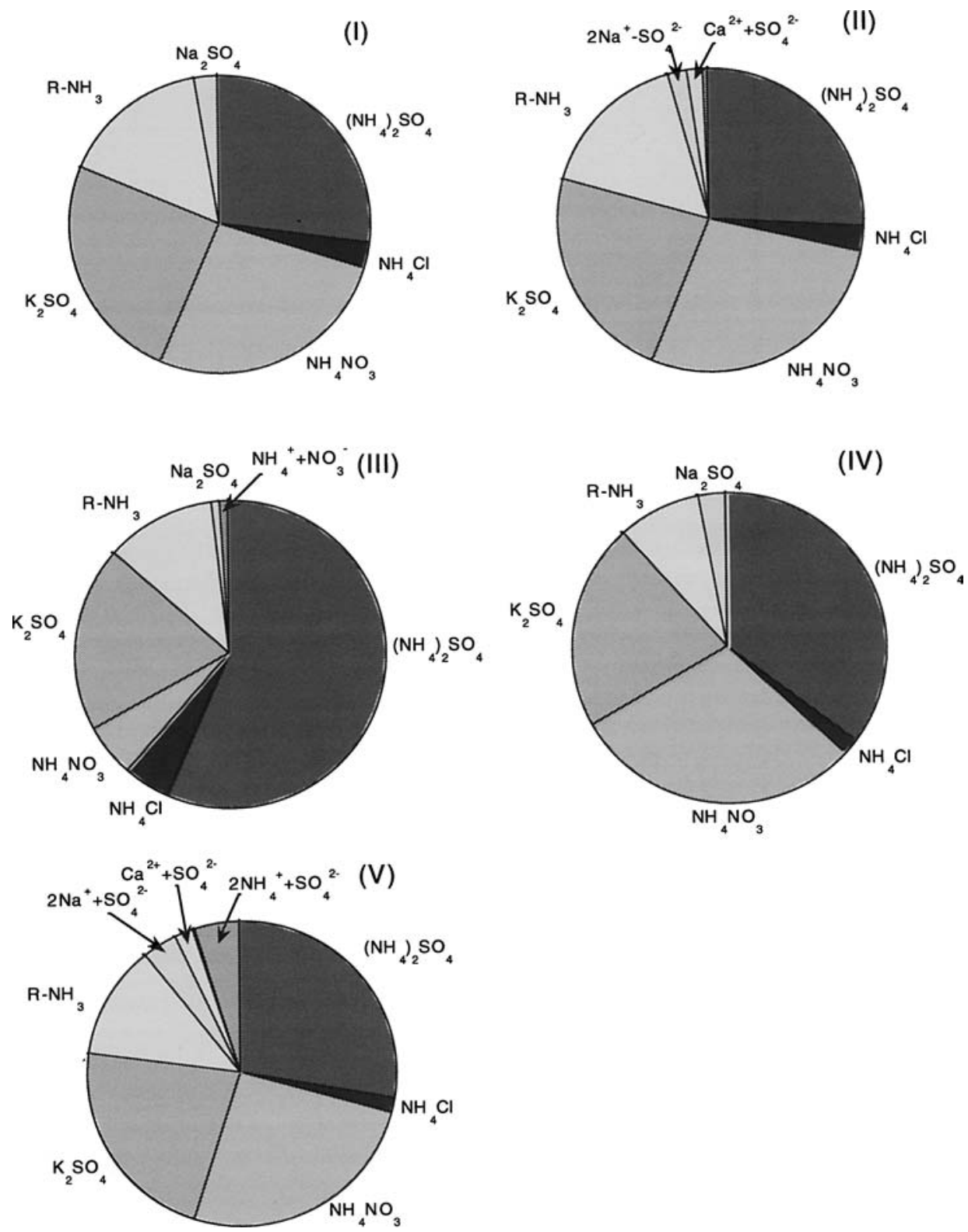

Figure 4. Aerosol composition predicted by SCAPE II with the assumption of internal mixture for the five measurement points of P3B Flight \#10 (shown in Table I). The pie-charts are on a mass basis.

particles traveled along the air mass trajectory, being separated from each other to some degree.

Note that the one mechanism by which two particles become internal mixture is coagulation. However, in our situation in which we only focus on the fine particle 
composition, coagulation is expected to be a slow process because the coagulation coefficients for similar sized particles are very small (Wexler et al., 1994; Seinfeld and Pandis, 1998).

To estimate the degree of external mixing of $\left(\mathrm{NH}_{4}\right)_{2} \mathrm{SO}_{4}$, the following formula for $\mathrm{DEM}_{\mathrm{SO}_{4}}$ is defined:

$$
\text { Degree of External Mixing }(\%)=\frac{\left[\left(\mathrm{NH}_{4}\right)_{2} \mathrm{SO}_{4}\right]_{\mathrm{ext}}}{\left[\left(\mathrm{NH}_{4}\right)_{2} \mathrm{SO}_{4}\right]_{\mathrm{tot}}} \times 100
$$

where $\left[\left(\mathrm{NH}_{4}\right)_{2} \mathrm{SO}_{4}\right]_{\text {tot }}$ and $\left[\left(\mathrm{NH}_{4}\right)_{2} \mathrm{SO}_{4}\right]_{\text {ext }}$ indicate the total mass of $\left(\mathrm{NH}_{4}\right)_{2} \mathrm{SO}_{4}$ measured and the mass of $\left(\mathrm{NH}_{4}\right)_{2} \mathrm{SO}_{4}$ that exists externally to the other ionic constituents (e.g., $\mathrm{K}^{+}$and $\mathrm{NO}_{3}^{-}$), respectively. In this analysis, a 2-to-1 molar ratio of $\mathrm{NH}_{4}^{+}$to $\mathrm{SO}_{4}^{2-}$ is taken out from the bulk internal mixture. Also, the possibility of $\mathrm{NH}_{4} \mathrm{HSO}_{4}$ formation is excluded since the complete system is very "cation-rich", and in these types of systems, $\mathrm{NH}_{4} \mathrm{HSO}_{4}$ formation is atypical (Kim and Seinfeld, 1993a,b).

Figure 5 summarizes the composition changes in the observed BB aerosol particles with respect to the degree of external mixing $\left(\mathrm{DEM}_{\mathrm{SO}_{4}}\right)$ for two representative cases; II and IV from Table I. Although the other results are not shown, the general trends in the aerosol compositional changes with $\mathrm{DEM}_{\mathrm{SO}_{4}}$ are similar. As clearly shown in Figure 5, for the measured concentrations of the various ions in the BB plume, the aerosol composition dramatically changes with the $\mathrm{DEM}_{\mathrm{SO}_{4}}$ when the $\mathrm{DEM}_{\mathrm{SO}_{4}}$ reaches approximately $60 \%$. At this point $\mathrm{KNO}_{3}$ starts to be thermodynamically favored, whereas both $\mathrm{K}_{2} \mathrm{SO}_{4}$ and $\mathrm{NH}_{4} \mathrm{NO}_{3}$ begin to decrease. In other words, $\mathrm{SO}_{4}^{2-}$ starts to yield $\mathrm{K}^{+}$to $\mathrm{NO}_{3}^{-}$. As the $\mathrm{DEM}_{\mathrm{SO}_{4}}$ increases from $60 \%$ to $100 \%, \mathrm{KNO}_{3}$ formation increases linearly, whereas the concentrations of $\mathrm{K}_{2} \mathrm{SO}_{4}$ and $\mathrm{NH}_{4} \mathrm{NO}_{3}$ steadily decrease. Note, however, that the amount of $\mathrm{NH}_{4} \mathrm{Cl}$ is not affected by the $\mathrm{DEM}_{\mathrm{SO}_{4}}$. Not shown are $\mathrm{R}-\mathrm{NH}_{3}$ concentrations, because $\mathrm{R}-\mathrm{NH}_{3}$ could exist either with BB particles or by themselves. Even if they exist with the $\mathrm{BB}$ particles, their predicted concentrations stay at fairly constant values throughout the whole range of $\mathrm{DEM}_{\mathrm{SO}_{4}}$.

Comparing the data correlations and molar ratios to the predictions of the aerosol thermodynamic analysis, it could be concluded that the tropical forest burning aerosol components (e.g., $\mathrm{K}^{+}$) are mixed externally with the background and the secondarily formed accumulation-mode particles (e.g., $\mathrm{SO}_{4}^{2-}$ ), and that the $\mathrm{DEM}_{\mathrm{SO}_{4}}$ is between $60-100 \%$ in terms of the existence of $\mathrm{KNO}_{3}$. However, we speculate that the degree of external mixing is likely larger than $\sim 90 \%$, based on inferred levels of both $\mathrm{KNO}_{3}$ and $\mathrm{NH}_{4} \mathrm{NO}_{3}$. As shown in Figure 3(a) and (c), we predicted $\mathrm{KNO}_{3}$ is the major salt in the BB particles and $\mathrm{NH}_{4} \mathrm{NO}_{3}$ could be a minor salt. When $\mathrm{DEM}_{\mathrm{SO}_{4}}$ is larger than $\sim 90 \%$, the amounts of $\mathrm{KNO}_{3}$ becomes larger than $\mathrm{NH}_{4} \mathrm{NO}_{3}$ (i.e., $\mathrm{KNO}_{3}$ becomes the major $\mathrm{NO}_{3}^{-}$-associated salt from this point, and $\mathrm{NH}_{4} \mathrm{NO}_{3}$ becomes a minor salt).

In this case study, water-soluble organics generated from biomass burning activities were not measured. Since the SCAPE model does not include these 
" $100 \%$ internal mixture"
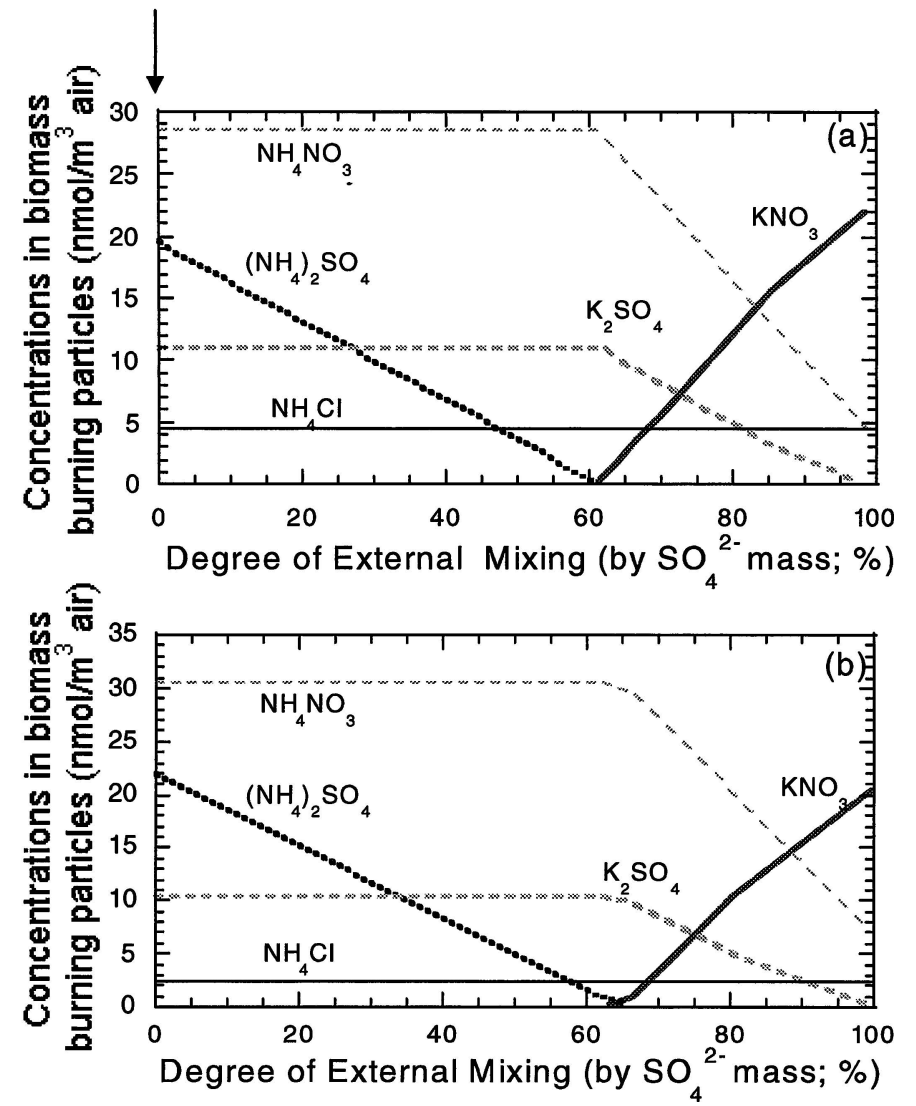

Figure 5. Variations in the biomass burning (BB) aerosol composition with respect to degree of external mixing $\left(\mathrm{DEM}_{\mathrm{SO}_{4}}\right)$ : (a) for measurement point II; and (b) for measurement point IV of Table I.

water-soluble organic anions, there is some uncertainty regarding their role. However, considering their volatile nature, the thermodynamic affinity of these organic anions to non-volatile $\mathrm{K}^{+}$could be very weak, which led us to conjecture that $\mathrm{R}-\mathrm{NH}_{3}$ is probably associated with the unmeasured organic anions. Possible association between $\mathrm{NH}_{4}^{+}$and organic anions are discussed elsewhere (Tabazadeh et al., 1998; Gao et al., 2003). Therefore, the existences of the water-soluble organics may not alter our conclusion. The major focus of this study is on associations between $\mathrm{K}^{+} / \mathrm{NH}_{4}^{+}$and $\mathrm{SO}_{4}^{2-} / \mathrm{NO}_{3}^{-}$, which should not be significantly altered by the amount of water-soluble organics in our modeling situations.

\section{Spatial Variability and Measurement Integration Periods}

The methodology employed to explore the aerosol mixing state of various fine particle ionic constituents depends on the associations between ion pairs, based on the 
3.5-min integrated composition measurements. Possible anion-cation associations are inferred from correlation and molar ratio analyses. However, there are situations where the associations could lead to spurious conclusions as to the real ion associations. One case could occur in air masses in which the chemical composition of the aerosol particles is highly variable and the plumes are not well mixed. This would occur if sampling near a variety of strong point sources, such as in an urban area. In this case, during the $\sim 3.5$-min measurement integration period, one could sample several distinct plumes of different composition. However, unlike urban air masses, aged air parcels in remote regions have more spatially uniform concentrations and would likely not have a high degree of variability over the $3.5 \mathrm{~min}$ integration period. In the remote areas investigated in this work, $1 \mathrm{~Hz}$ data of $\mathrm{O}_{3}$, $\mathrm{SO}_{2}$, and $\mathrm{NO} / \mathrm{NO}_{\mathrm{y}}$ concentrations (fast response species as a proxy indicator for the degree of variability of the aerosol mixing) indicate that the air parcels are fairly well mixed. For the complete data set, roughly $90 \%$ of the measurement legs have almost uniform composition over the 3.5-min time span. One example of uniform composition over the 3.5-min sampling period is shown in Figure 6. We conclude that in the air masses investigated here, a high degree of spatial variability is not sufficient to confound the analysis of association between ion pairs and inferred mixing state of selected ions.

In addition, our study has been based on the analysis of an ensemble of data points that belong to a "homogeneous plume" (in this study, the plume is influenced by a spatially large source apparently of similar BB emissions). Thus this plume is expected to be composed of similar constituents with some degree of varying
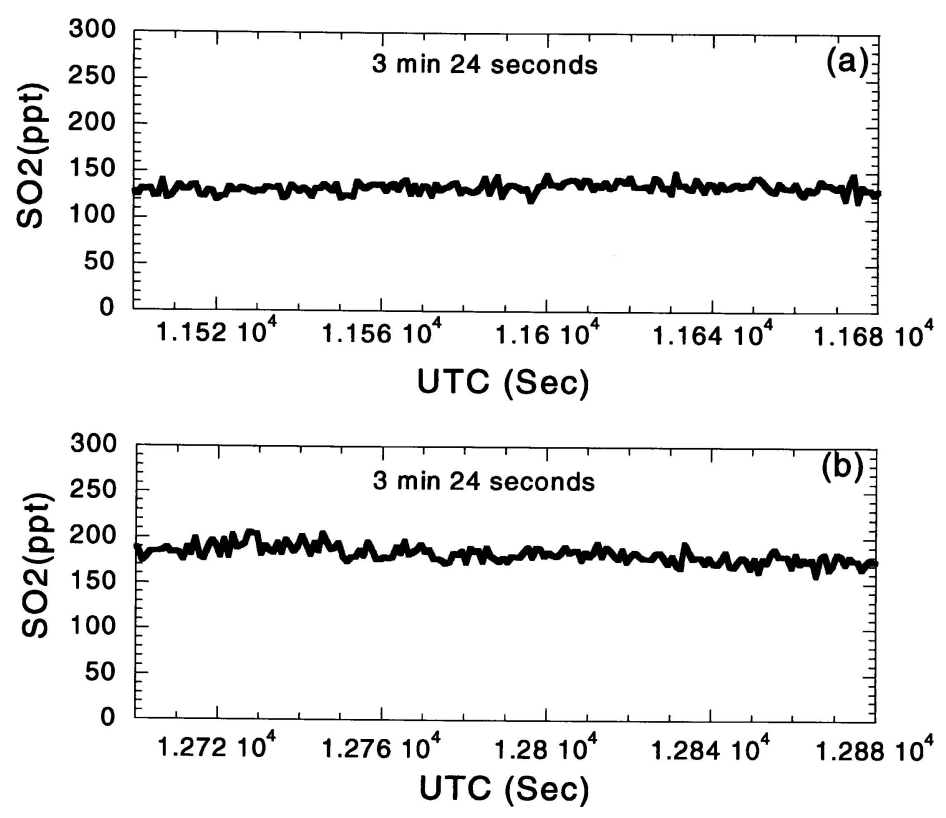

Figure 6. Fast response species $\left(\mathrm{SO}_{2}\right)$ concentrations over the two 3 min integration periods. 
concentrations. The different species concentrations could result from the different intensities of BB activities (e.g., flaming or smoldering) over the burning regions. However, over the PILS-IC integration time span (i.e., $3.5 \mathrm{~min}$ ), the concentrations are fairly uniform, as shown in Figure 6. Thus, although the PILS-IC measurement is a bulk particulate concentration measurement, it is both the variability over the complete measurement leg $(1 \mathrm{~h} 20 \mathrm{~min})$ and uniformity over the instrument integration time span $(3.5 \mathrm{~min})$ that are the bases for investigating the aerosol ion associations and aerosol-mixing state.

\section{The Effect of Aerosol Mixing State on Water Uptake by Particles}

Chemical composition of individual particles is important because it affects how the particles interact with gases through condensation and evaporation, and thus how the particles chemically evolve. It is noted that in this work we have only focused on the fine mode. The relative importance of the fine/coarse particles on particlegas interactions can be partly estimated from Fuchs-Sutugin coefficients (Fuchs and Sutugin, 1970). In the biomass plume of P3B Flight \#10, based on measured size distributions (A. Clarke, University of Hawaii) the fine-mode Fuchs-Sutugin mass transfer coefficient dominates the ratios of fine to coarse-mode. In this case the ratios are 102.6 for $\mathrm{H}_{2} \mathrm{SO}_{4}(\gamma=0.5), 42.5$ for $\mathrm{HNO}_{3}$ and $\mathrm{NH}_{3}(\gamma=0.1)$, and 16.2 for $\mathrm{SO}_{2}\left(\gamma=10^{-4}\right)$, and the fine (accumulation) mode dominates the heterogeneous chemistry in this plume.

Aerosol-mixing state also plays an important role in the particle growth by water condensation/evaporation, which in-turn influences the particles optical properties (e.g., Tang, 1996, 1997; Malm et al., 2000a,b; Derek et al., 2000). The change in particle hygroscopicity with the aerosol-mixing state based on the simulation results for the BB plume measured on TRACE-P Flight 10 are given in Table II.

Table II. Amounts of particulate water $\left(\mu \mathrm{g} / \mathrm{m}^{3}\right.$ air) estimated for measurement point II of P3B Flight \#10 for internal and external mixture with an $85 \%$ degree of external mixing

\begin{tabular}{ccccc}
\hline & & \multicolumn{3}{c}{ External mixture $(\mathrm{DEM}=85 \%)$} \\
\cline { 3 - 5 } RH & Internal mixture & $\mathrm{BB}$ & $\mathrm{BG}$ & Total \\
\hline 0.5 & 0.0 & 0.0 & 0.0 & 0.0 \\
0.6 & 3.1 & 0.9 & 0.0 & 0.9 \\
0.7 & 4.5 & 1.4 & 0.0 & 1.4 \\
0.8 & 8.0 & 2.5 & 4.7 & 7.2 \\
0.9 & 18.1 & 7.6 & 8.9 & 16.5 \\
\hline
\end{tabular}

Note. BB represents the biomass burning particles; BG represents the background particles. Total water amounts in external mixture are made by adding up water amounts of BB and BG particles. The amounts of particulate water are estimated using the ZSR method. 
The table estimates the amount of water taken up for internal versus external $\left(\mathrm{DEM}_{\mathrm{SO}_{4}}=85 \%\right)$ mixtures when exposed to different relative humidities. The amounts of particulate water are estimated by the ZSR method (Zdanovskii-StokesRobinson) (Stokes and Robinson, 1966). The table shows that when, for example, the internally mixed aerosol is exposed to a RH of 0.7 , it takes up $4.5 \mu \mathrm{g} / \mathrm{m}^{3}$ of liquid water, whereas for the externally mixed biomass burning particles (BB) and background particles (BG) the water uptake is 1.4 and $0.0 \mu \mathrm{g} / \mathrm{m}^{3}$, respectively. A similar situation occurs for all relative humidities; the internal mixtures are generally more hygroscopic than the external mixture. It is pointed out that these calculations only consider the inorganic aerosol fraction. The role of carbonaceous compounds on the particle water up-take cannot be addressed since no measurements were made of either the water-soluble organic fraction or the total organic and elemental carbon mass.

\section{Conclusions}

Three and one-half minute integrated aerosol inorganic composition data from airborne measurements during TRACE-P P3B Flight 10 are analyzed to investigate the chemical composition and possible mixing state of fine-mode biomass burning (BB) particles. A BB plume was detected over the Philippine Sea at $\sim 3 \mathrm{~km}$ above sea level. Five day backward trajectories suggest the biomass plume was injected into the atmosphere roughly 3-4 days prior to the airborne measurements. Correlations and molar charge ratios (equivalence ratios) between various ionic compounds are consistent with the presence of $\mathrm{KNO}_{3},\left(\mathrm{NH}_{4}\right)_{2} \mathrm{SO}_{4}$, and $\mathrm{NH}_{4}$ (Organics) salts. The prevalence of $\mathrm{KNO}_{3}$ in fine-mode particles is used to investigate the mixing state of the $\mathrm{BB}$ aerosols by comparing to the results of a "close-mode" thermodynamic aerosol simulation. In the thermodynamic aerosol simulation, the $\mathrm{KNO}_{3}$ combination is less favored in the $\mathrm{K}^{+}-\mathrm{NH}_{4}^{+}-\mathrm{NO}_{3}^{-}-\mathrm{SO}_{4}^{2-}$-Organic anions system than $\mathrm{K}_{2} \mathrm{SO}_{4}$. This discrepancy suggests a largely external mixture of $\mathrm{BB}$ particle- $\mathrm{K}^{+}$with any entrained background or secondarily formed accumulation-mode $\mathrm{SO}_{4}^{2-}$ particles. The degree of external mixing (by $\mathrm{SO}_{4}^{2-}$ mass) is estimated to be between 60 and $100 \%$. However, it is likely larger than $\sim 90 \%$ based on the inferred relative concentrations of $\mathrm{KNO}_{3}$ and $\mathrm{NH}_{4} \mathrm{NO}_{3}$.

Other BB plumes were also encountered by the NASA P3B aircraft during TRACE-P, such as Flights 14 and 19 over the Yellow Sea and Sea of Japan, respectively (Ma et al., 2003). These plumes contained complicated mixtures of inorganic aerosol constituents due to the mix of sources, which included bio-fuel and fossil fuel emissions, and natural aerosols such as dust and sea-salt particles and are thus difficult to analyze with our methodology.

Finally, it is noted that the observed correlations between ions do not prove ionassociations and that particle mixing state can only be unambiguously determined through single particle chemical analysis. However, the method used here for measuring particle composition is likely more quantitative than current single particle 
analysis methods and thus a combination of the two approaches could provide unique insights.

\section{Acknowledgements}

The study was financially supported by the National Science Foundation under contract ATM-0080471 and the National Aeronautics and Space Administration under contract NCC-1-411.

\section{References}

Adams, P. J., Seinfeld, J. H., and Koch, D. M., 1999: Global concentrations of tropospheric sulfate, nitrate, and ammonium aerosol simulated in a general circulation model, J. Geophys. Res. 104(D11), 13791-13823.

Allan, J. D., Alfarra, M. R., Bower, K. N., Williams, P. I., Gallagher, M. W., Jimenez, J. L., McDonald, A. G., Nemitz, E., Canagaratna, M. R., Jayne, J. T., Coe, H., and Worsnop, D. R., 2003: Quantitative sampling using an Aerodyne aerosol mass spectrometer - 2. Measurements of fine particulate chemical composition in two U.K. cities, J. Geophys. Res. 108(D3), 4091.

Andreae, M. O., 1983: Soot carbon and excess fine potassium: Long-range transport of combustionderived aerosols, Science 220, 1148-1151.

Andreae, M. O., 1988: Biomass-burning emissions and associated haze layers over Amazonia, $J$. Geophys. Res. 93, 1509.

Andreae, M. O. and Merlet, P., 2001: Emission of trace gases and aerosols from biomass burning, Global Biogeochem. Cycles 15, 955-966.

Bassett, M. E. and Seinfeld, J. H., 1983: Atmospheric equilibrium model of sulfate and nitrate aerosols, Atmos. Env. 17, 2237-2252.

Clarke, A.D., Shinozuka, Y., Kapustin, V. N., Howell, S., Huebert, B., Masonis, S., Anderson, T., Covert, D., Weber, R., Anderson, J., Zin, H., Moore II, K. G., and McNaughton, C., 2004: Sizedistributions and mixtures of black carbon and dust aerosol in Asian outflow: Physico-chemistry, optical properties, and implications for $\mathrm{CCN}$ (in preparation).

Cooke, W. F. and Wilson, J. J. N., 1996: A global black carbon aerosol model, J. Geophys. Res. 101, 19395-19409.

Covert, D. S. and Heintzenberg, J., 1984: Measurement of the degree of internal/external mixing of hygroscopic compounds and soot in atmospheric aerosol, Sci. Total Environ. 36, 347352.

Day, D. E., Malm, W. C., and Kreidenweis, S. M., 2000: Aerosol light scattering measurements as a function of relative humidity, J. Air Water Manage. Assoc., 710-716.

Eldering, A. and Cass, G. R., 1996: Source-oriented model for air pollutant effects on visibility, J. Geophys. Res. 101, 19343-19369.

Fuchs N. A. and Sutugin, A. G., 1970: Highly Dispersed Aerosol, Ann Arbor Science, Ann Arbor, MI.

Gao S., Hegg, D. A., Hobbs, P. V., Kirchstetter, T. W., Magi, B. I., and Sadilek, M., 2003: Watersoluble organic components in aerosols associated with savanna fires in southern Africa: Identification, evolution, and distribution, J. Geophys. Res. 108(D13), 8491, doi:10.1029/002002JD002324.

Guazzotti, S. A., Coffee, K. R., and Prather, K. A., 2001: Continuous measurements of size-resolved particle chemistry during INDOEX - Intensive Field Phase 99, J. Geophys. Res. 106(D22), 28607-28627. 
Haywood, J. M., Roberts, D. L., Slingo, A., Edwards, J. M., and Shine, K. P., 1997: General circulation model calculations of the direct radiative forcing by anthropogenic sulfate and fossil-fuel soot aerosol, J. Climate 10, 1562-1577.

Hinds, W. C., 1982: Aerosol Technology: Properties, Behavior, and Measurement of Airborne Particles, Wiley, New York.

Huebert, B. J., Howell, S. G., Covert, D., Bertram, T., Clarke, A. C., Anderson, J. R., Lafleur, B. G., Seebaugh, R., Wilson, J. C., Gesler, D., Blomquist, B., and Fox, J. PELTI: Measuring the passing efficiency of an airborne low turbulence aerosol inlet. Aerosol Sci. Technol. (in review).

Jacob, D. J., Crawford, J., Kleb, M. M., Conners, V. S., Bendura, R. J., Raper, J. L., Sachse, G. W., Gille, J., Emmons, L., and Herald, J. C., 2003: Transport and chemical evolution over the Pacific (TRACE-P) mission: Design, execution, and first results, J. Geophys. Res. 108(D20), 8781, doi:10.10291/2002JD003276.

Jacobson, M. Z., Tabazadeh, A., and Turco, R. P., 1996: Simulating equilibrium with aerosols and non-equilibrium between gases and aerosols, J. Geophys. Res. 101, 9079-9091.

Janicke, R., 1993: Aerosols-Clouds-Climate interactions, in P. V. Hobbs (ed.), Tropospheric Aerosols, Academic Press, San Diego, CA, pp. 1-31.

Kaufman, Y. J. and Fraser, R. S., 1997: The effect of smoke particles on clouds and climate forcing, Science 277, 1636-1639.

Kim, Y. P. and Seinfeld, J. H., 1993a: Atmospheric gas-aerosol equilibrium I. Thermodynamic model, Aerosol Sci. Technol. 19, 157-181.

Kim, Y. P. and Seinfeld, J. H., 1993b: Atmospheric gas-aerosol equilibrium II. Thermodynamic model, Aerosol Sci. Technol. 19, 182-198.

Kleeman, M. J., Cass, G. R., and Eldering, A., 1997: Modeling the airborne particle complex as a source-oriented external mixture, J. Geophys. Res. 102, 21355-21372.

Korhnon, P., Kulmala, M., Laaksonen, A., Viisanen, Y., McGraw, R., and Seinfeld, J. H., 1999: Ternary nucleation of $\mathrm{H}_{2} \mathrm{SO}_{4}, \mathrm{NH}_{3}$, and $\mathrm{H}_{2} \mathrm{O}$ in the atmosphere, J. Geophys. Res. 104, 2634926353.

Li, J., Posfai, M., Hobbs, P. V., and Buseck, P., 2003: Individual aerosol particles from biomass burning in southern Africa: 2. Compositions and aging of inorganic particles, J. Geophys. Res. 108(D13), 8484, doi:10.1029/002002JD002310.

Ma, Y., Rodney, R. J., Lee, Y.-N., Thornton, D. C., Bandy, A. R., Clarke, A. D., Blake, D. R., Sachse, G. W., Fuelberg, H. E., Kiley, C. M., Woo, J.-H., Streets, D. G., Carmichael, G. R., and Eisele, F. L., 2003: The characteristics and influence of biosmoke on fine particle ionic composition measured in Asian outflow during TRACE-P, J. Geophys. Res. 108, 8816, doi:10.1029/2002JD003128.

Malm, W. C., Day, D. E., and Kreidenweis, S. M., 2000a: Light scattering characteristics of aerosols as a function of relative humidity: Part I - A comparison of measured scattering and aerosol concentrations using the theoretical models, J. Air Water Manage. Assoc. 686-700.

Malm, W. C., Day, D. E., and Kreidenweis, S. M., 2000b: Light scattering characteristics of aerosols as a function of relative humidity: Part II - A comparison of measured scattering and aerosol concentrations using the statistical models, J. Air Water Manage. Assoc. 701-709.

Meng, Z., Seinfeld, J. H., Saxena, P., and Kim, Y. P., 1995: Atmospheric gas-aerosol equilibrium IV. Thermodynamics of carbonates, Aerosol Sci. Technol. 23, 131-154.

Meng, Z., Dabdub, D., and Seinfeld, J. H., 1998: Size-resolved and chemically resolved model of atmospheric aerosol dynamics, J. Geophys. Res. 103, 3419-3435.

Meszaros, A. and Meszaros, E., 1989: Sulfate formation on elemental carbon particles, Aerosol Sci. Technol. 10, 337-342.

Murphy, D. M., Thomas, D. S., and Mahoney, T. M. J. 1998: In situ measurements of organics, meteoritic material, mercury, and other elements in aerosols at 5 to 19 kilometers, Science $\mathbf{2 8 2}$, $1664-1669$. 
Napari, I., Kulmala, M., and Vehkamaki, H., 2002: Ternary nucleation of inorganic acids, ammonia, and water, J. Chem. Phys. 117, 8418-8425.

Neuman J. A., Nowak, J. B., Brock, C. A., Trainer, M., Fehsenfeld, F. C., Holloway, J. S., Hübler, G., Hudson, P. K., Murphy, D. M., Nicks Jr., D. K., Orsini, D., Parrish, D. D., Ryerson, T. B., Sueper, D. T., Sullivan, A., and Weber, R., 2003: Variability in ammonium nitrate formation and nitric acid depletion with altitude and location over California, J. Geophys. Res. Atmos. 108(D17), 4557, doi:10.1029/2003JD003616.

Novakov, T., Chang, S. G., and Harker, A. B., 1974: Sulfates as pollution particles: Catalytic formation on carbon (soot) particles, Science 186, 259-261.

Orsini, D., Ma, Y., Sullivan, A., Sierau, B., Baumann, K., and Weber, R., 2003: Refinements to the particle-into-liquid sampler (PILS) for ground and airborne measurements of water soluble aerosol composition, Atmos. Enviorn 37, 1243-1259.

Parungo, F., Nagomoto, C., Zhou, M., Hansen, A. D., and Harris, J., 1994: Aeolian transport of aerosol black carbon from China to ocean, Atmos. Enviorn 28, 3251-3260.

Parungo, F. C., et al., 1996: Asian Dust Storms and Their Effects on Radiation and Climate, Technical Report 2959, STC, National Oceanic and Atmospheric Administration, Silver Springs, MD.

Penner, J. E., Dickinson, R. E., and O'Neil, C. A., 1992: Effects of aerosol from biomass burning on the global radiation budget, Science 256, 1432-1434.

Posfai, M., Simonics, R., Li, J., Hobbs, P. V., and Buseck, P. R., 2003: Individual aerosol particles from biomass burning in southern Africa: 1. Compositions and size distributions of carbonaceous particles, J. Geophys. Res. 108(D13), 8483, doi:10.1029/002002JD002291.

Seinfeld, J. H. and Pandis, S. N., 1998: Atmospheric Chemistry and Physics, Wiley, New York, pp. $537-539$.

Sinha, P., Hobbs, P. V., Yokelson, R. J., Bertschi, I. T., Blake, D. R., Simpson, I. J., Gao, S., Kirchstetter, T. W., and Novakov, T., 2003: Emissions of trace gases and particles from savanna fires in southern Africa, J. Geophys. Res. 108(D13), 8487, doi:10.1029/2002JD002325.

Stokes, R. H. and Robinson, R. A., 1966: Interactions in aqueous nonelectrolyte solutions. I. Solute-solvent equilibria, J. Phys. Chem. 70, 2126-2130.

Tabazadeh, A., Jacobson, M. Z., Singh, H. B., Toon, O. B., Lin, J. S., Chatfield, R. B., Thakur, A. N., Talbot, R. W., and Dibb, J. E., 1998: Nitric acid scavenging by mineral and biomass burning aerosols, Geophys. Res. Lett. 25, 4185-4188.

Talbot, R. W., Andreae, M. O., Andreae, T. W., and Harris, R. C., 1988: Regional aerosol chemistry of the Amazon basin during the dry season, J. Geophys. Res. 93, 1499.

Talbot, R. W., Dibb, J. E., and Loomis, M. B., 1998: Influence of vertical transport on free tropospheric aerosols over the central USA in springtime, Geophys. Res. Lett. 25, 13671370.

Tang, I. N., 1996: Chemical and size effects of hygroscopic aerosols on light scattering coefficients, J. Geophys. Res. 101, 19245-19250.

Tang, I. N., 1997: Thermodynamic and optical properties of mixed-salt aerosols of atmospheric importance, J. Geophys. Res. 102, 1883-1893.

Weber, R. J., McMurry, P. H., Mauldin, L., Tanner, D. J., Eisele, F. L., Brechtel, F. J., Kreidenweis, S. M., Kok, G. L., Schillawski, R. D., and Baumgarden, D., 1998: A study of new particle formation and growth involving biogenic and trace gas species measured during ACE1, $J$. Geophys. Res. 103, 16385-16396.

Weber, R. J., Orsini, D., Daun, Y., Lee, Y.-N., Klotz, P., and Brechtel, F., 2001: A particle-into-liquid collector for rapid measurements of aerosol chemical composition, Aerosol Sci. Technol. 35, 718-727.

Wexler, A. S., Lurmann, F. W., and Seinfeld, J. H., 1994: Modeling urban and regional aerosols - I. Model development, Atmos. Env. 28, 531-546. 
Yamasoe, M. A., Artaxo, P., Miguel, A. H., and Allen, A. G., 2000: Chemical composition of aerosol particles from direct emissions of vegetation fires in the Amazon Basin: Watersoluble species and trace elements, Atmos. Env. 34, 1641-1653.

Zhang, D., Zhang, J., Shi, G., Iwasaka, Y., Matsuki, A., and Trochkine, D., 2003: Mixture state of individual Asian dust particles at a coastal site of Qingdao, China, Atmos. Enviorn 37, 3895-3901.

Zhang, X. Q., McMurry, P. H., Hering, S. V., and Casuccio, G. S., 1993: Mixing characteristics and water content of submicron aerosols measured in Los Angeles and at the Grand Canyon, Atmos. Enviorn 27A, 1593-1607. 